\title{
Alaskan marine transgressions record out-of-phase Arctic Ocean glaciation during the last interglacial \\ Louise Farquharson $^{1 *}$, Daniel Mann ${ }^{2}$, Tammy Rittenour ${ }^{3}$, Pamela Groves ${ }^{4}$, Guido Grosse ${ }^{5}$, Benjamin Jones $^{6}$ \\ ${ }^{1}$ Geophysical Institute Permafrost Laboratory, University of Alaska Fairbanks, Fairbanks, Alaska, USA \\ ${ }^{2}$ Department of Geosciences, University of Alaska Fairbanks, Fairbanks, Alaska, USA \\ ${ }^{3}$ Department of Geology, Utah State University, Logan, Utah, USA \\ ${ }^{4}$ Institute of Arctic Biology, University of Alaska Fairbanks, Fairbanks, Alaska, USA \\ ${ }^{5}$ Alfred Wegener Institute Helmholtz Centre for Polar and Marine Research, Potsdam, Germany \\ ${ }^{6}$ Water and Environmental Research Center, Institute of Northern Engineering, University of Alaska Fairbanks, Fairbanks, Alaska 99775, USA \\ *Corresponding author, email: lmfarquharson@alaska.edu
}

\section{Contents}

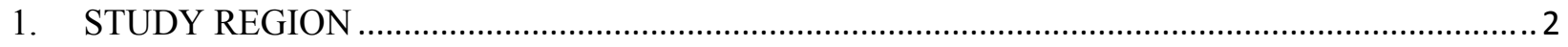

Figure DR1: The Arctic Ocean basin with the location of Figure 1 outlined in black.............. 2

Table DR1: Locations of sections sampled.................................................................... 3

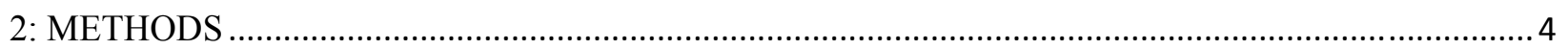

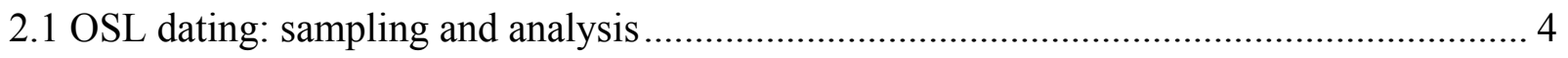

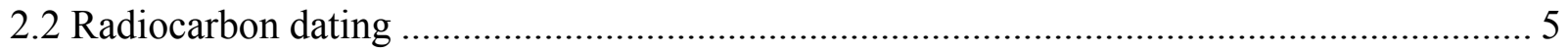

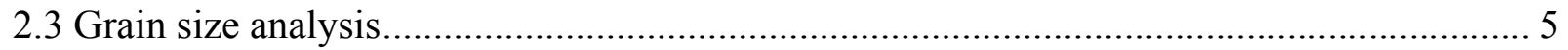

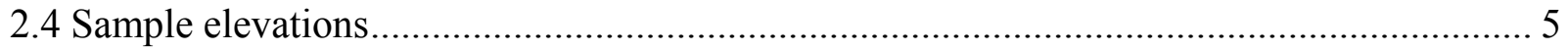

Table DR-2: Dose rate information for Pelukian and Walrus Bluff luminescence samples....... 6

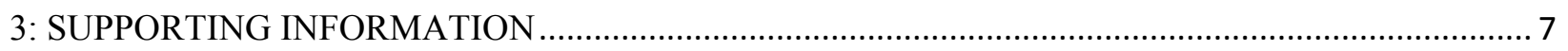

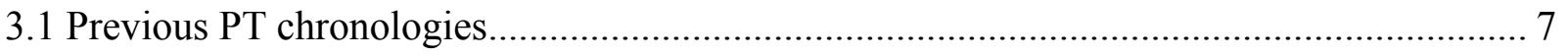

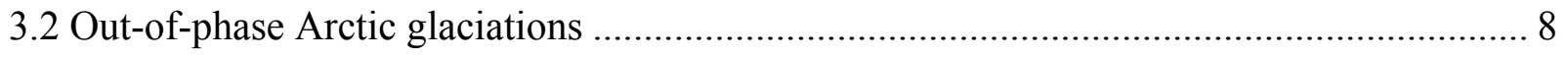

Figure DR 2: The high-latitude out-of-phase glaciation mechanism ................................. 10

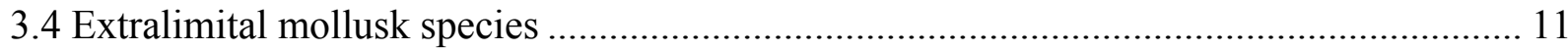

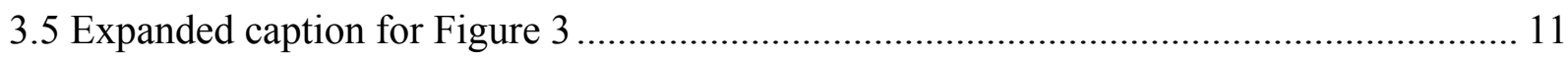

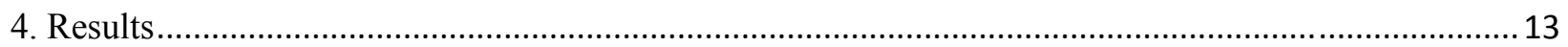

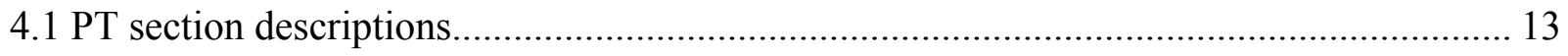

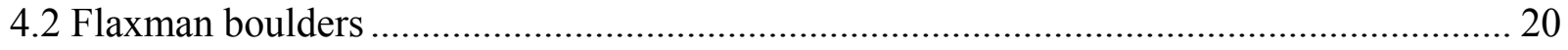

Data repository 
Figure DR3: The out-of-phase glaciation mechanism ..............................21

Figure DR4: Walrus Bluff with designated units and OSL ages. Note that photo was taken before the section covering OSL sample from Unit 4 was excavated and cleaned. ............. 22

Figure DR5: Sedimentary features identified within the sections studied ........................... 23

Figure DR6: A sub-sample of fossils found in-situ........................................................ 24

Figure DR7: Grain size composition for Fox Cub Bluff................................................ 25

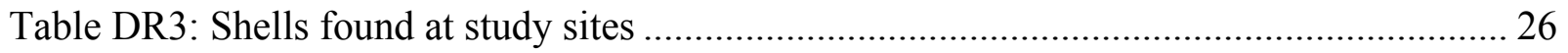

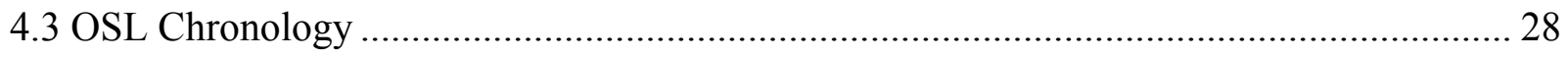

Table DR4: Optically stimulated luminescence ages.................................................... 29

Figure DR8: Quartz OSL Equivalent dose (DE) Radial Plots .......................................... 30

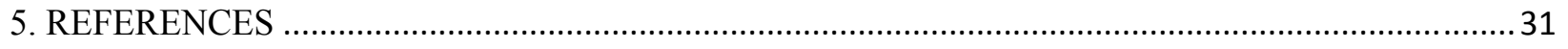

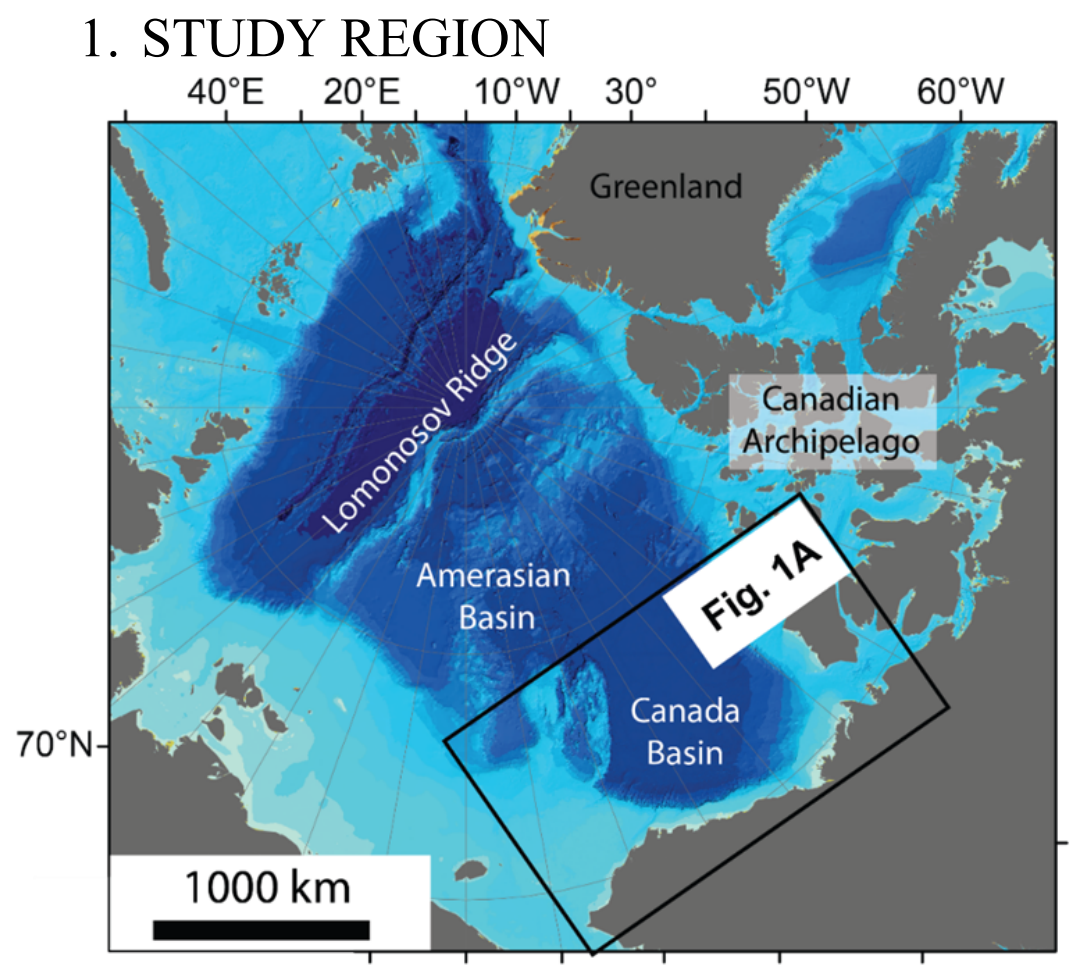

Figure DR1: The Arctic Ocean basin with the location of Figure 1 outlined in black. 
Table DR1: Locations of sections sampled

\begin{tabular}{lcc}
\hline & & \\
Section & Latitude & Longitude \\
\hline Admiralty Bay & $70.93^{\circ}$ & $-155.51^{\circ}$ \\
Walrus & $70.72^{\circ}$ & $-153.72^{\circ}$ \\
Drip & $70.72^{\circ}$ & $-153.71^{\circ}$ \\
Black Lagoon & $70.72^{\circ}$ & $-153.56^{\circ}$ \\
Fox Cub & $70.72^{\circ}$ & $-153.55^{\circ}$ \\
Lost Log & $70.72^{\circ}$ & $-153.72^{\circ}$
\end{tabular}




\section{2: METHODS}

2.1 OSL dating: sampling and analysis

We used the recommendations of Bateman and Murton (2006); Bateman (2008) and Forman et al., (2007) to tailor OSL sampling to the polar environment. Twelve samples were collected which span four geomorphic localities (Walrus, Black Lagoon, Ocean Bluff, and Drip).

Prior to luminescence sampling, sections of the bluff face were broadly exposed using hand tools and the stratigraphy was described. Sampling near unit boundaries and lithological unconformities were avoided. Equivalent dose $\left(\mathrm{D}_{\mathrm{E}}\right)$ samples were collected in opaque metal tubes (20-cm lengths of 4-cm (inner) diameter) and sediment within a $20-\mathrm{cm}$ radius surrounding the $\mathrm{D}_{\mathrm{E}}$ tube was uniformly sampled for radioelemental analysis and dose rate determination. Tube ends were capped with foam and sealed with duct tape. For in-situ gravimetric water content, a small amount (200-300 g) of sediment was sealed in an air-tight container.

OSL samples were opened and processed under dim amber safelight conditions at the Utah State University Luminescence Laboratory in Logan, Utah, USA. $\mathrm{D}_{\mathrm{E}}$ sample processing followed standard procedures (Wintle, 1997) involving: wet sieving to target a narrow grain size between 63-250 $\mu \mathrm{m}$ (see Table DR2), $\mathrm{HCl}$ acid treatment to remove carbonate minerals, bleach to remove organic material, heavy density liquid gravity separation (sodium polytungstate at $2.72 \mathrm{~g} / \mathrm{cm}^{3}$ for quartz and $2.58 \mathrm{~g} / \mathrm{cm}^{3}$ for feldspar), and concentrated HF acid treatment on quartz to dissolve remaining minerals and etch grain edges.

Dose rate samples were dried, homogenized and sub-sampled using a sample splitter before ICPMS and ICP-AES geochemical analysis to determine concentrations of radioelements $\mathrm{K}, \mathrm{Rb}, \mathrm{Th}$, and U using ICP-MS and ICP-AES techniques (Table DR2). Dose rate calculations include cosmic contribution to gamma dose rate using sample burial depth, elevation, and longitude/latitude following Prescott and Hutton (Prescott and Hutton, 1994), the influence of water content and attenuation on beta and gamma dose rates (Aitken, 1985; Aitken and Xie, 1990), chemical conversion factors (Guérin et al., 2011), beta attenuation coefficients (Brennan, 
2003), and uncertainty in elemental measurements (4-12\% depending on element and concentration).

Small-aliquots (2-mm) of quartz sand were analyzed following the latest single-aliquot regenerative-dose (SAR) procedures for OSL dating (Murray and Wintle, 2000a, 2003) ) $^{12}$. Samples were analyzed using Risø TL/OSL Model DA-20 readers with blue-green light emitting diodes (LEDs) $\left(470 \pm 30 \mathrm{~nm}\right.$ at $36-45 \mathrm{~mW} / \mathrm{cm}^{2}, 40-45$ second stimulation at $\left.125^{\circ} \mathrm{C}\right)$ as the OSL stimulation source (Bøtter-Jensen et al., 2003). The quartz-OSL signal was detected through 7.5mm UV filters (U-340). Equivalent dose $\left(D_{E}\right)$ values were determined using Central Age Model (CAM) of Galbraith and Roberts(Galbraith and Roberts, 2012). Errors on $\mathrm{D}_{\mathrm{E}}$ and age estimates are reported at 1-sigma standard error and include uncertainty related to instrument calibration, and dose rate and $\mathrm{D}_{\mathrm{E}}$ calculations follow the methods of Aitken and Alldred (Aitken and Alldred, 1972) and Guérin et al. (2011).

\subsection{Radiocarbon dating}

We used radiocarbon dating to ensure that material dated to mid- to late-Pleistocene by OSL was of non-finite (>40,000 cal yr BP) age. Herbaceous fragments and driftwood were sampled from coastal units at Walrus Bluff for radiocarbon dating. Samples were rinsed with distilled water and stored in ziplock bags until their shipment to Beta Analytic for analysis.

\subsection{Grain size analysis}

Samples were prepared for grain size analysis by removal of organic matter in hydrogen peroxide $\left(\mathrm{H}_{2} \mathrm{O}_{2}, 30 \%\right)$. Grain size distribution was measured with a laser particle size analyser (Coulter LS 200, Krefeld, Germany). Particles $<1 \mathrm{~mm}$ were analyzed in water, while particles $>1 \mathrm{~mm}$ were dry-sieved through a $2 \mathrm{~mm}$ mesh screen. We used GRADISTAT v8(Blott and Pye, 2001) for statistical analysis of grain size data.

\subsection{Sample elevations}

Elevations of sedimentary units and samples were established by identifying the height of lake level using a DGPS and then using measuring tapes from lake level up to bluff tops. 
Table DR-2: Dose rate information for Pelukian and Walrus Bluff luminescence samples

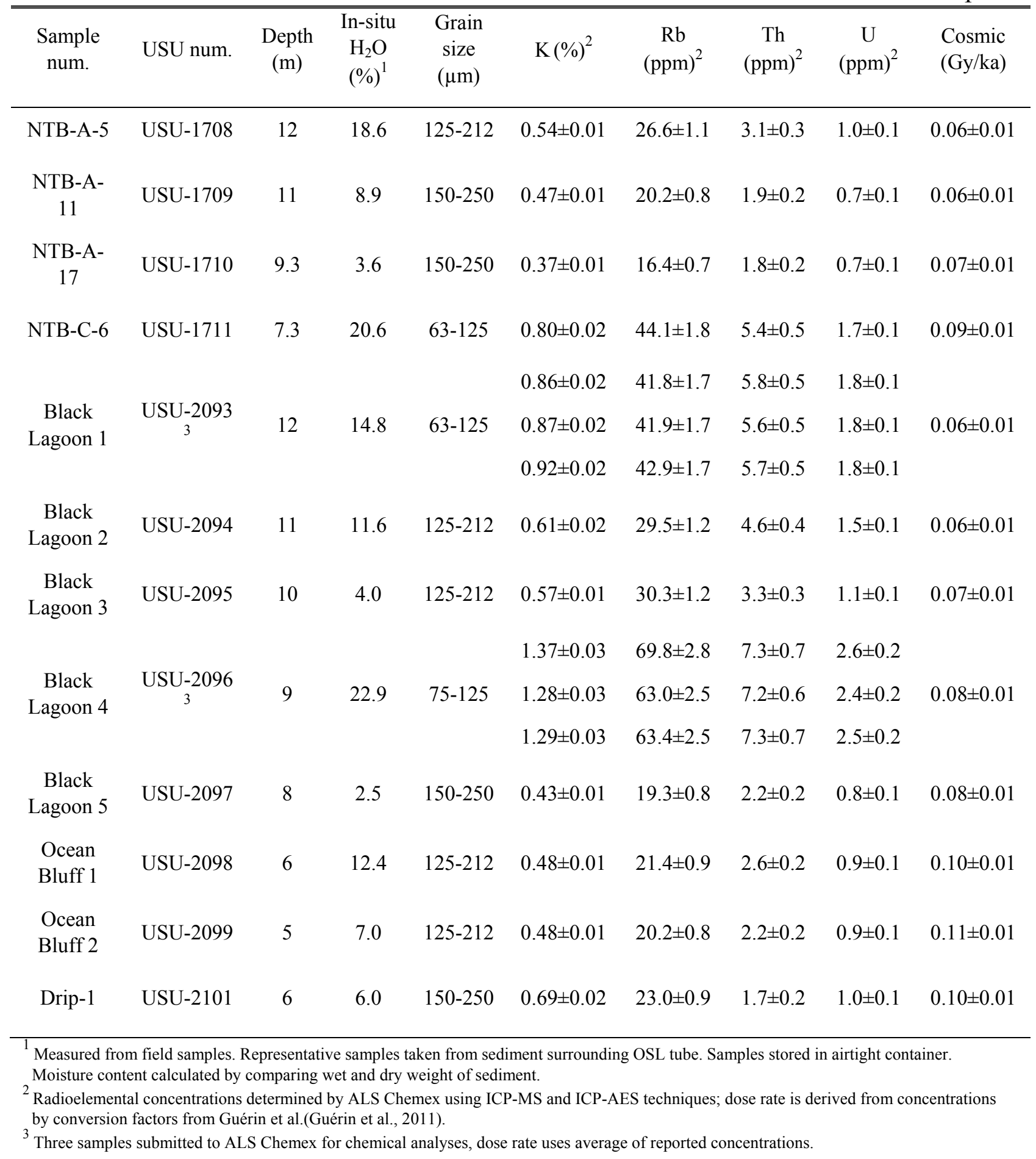

Data repository 


\section{3: SUPPORTING INFORMATION}

\subsection{Previous PT chronologies}

The altitude of PT deposits and the fact they contain marine mollusks whose range limits are now 100s of km further south, initially indicated this marine transgression represented the global RSL highstand during MIS 5e (Kaufman and Brigham-Grette, 1993a). Relative-age dating using amino-acid epimerization was used to support this inference (Kaufman and Brigham-Grette, 1993a; Brigham-Grette and Hopkins, 1995). However, while amino- acid epimerization is useful for correlating raised marine deposits on widely separated Arctic coasts at 100-ka time-scales (Kaufman and Brigham-Grette, 1993a), the method does not provide absolute age estimates (Miller and Brigham-Grette, 1989; Mangerud and Svendsen, 1992), and in Arctic Alaska racemization rates may be too slow to resolve age differences $<60 \mathrm{ka}$ (Brigham-Grette and Hopkins, 1995). Since the 1980s significant advances have been made in the methodology of optically stimulated luminescence dating (OSL) (Murray and Wintle, 2000b), and our understanding of Arctic Basin glaciations has also progressed (Jakobsson et al., 2014, 2016) prompting us to revisit these circum-arctic archives.

The age of the Pelukian Transgression remains uncertain in northern Alaska (Brigham-Grette and Hopkins, 1995) and Chukotka (Brigham-Grette et al., 2001). Hopkins (Hopkins, 1967) reported non-finite ${ }^{14} \mathrm{C}$ ages for shells from the Pelukian type section near Nome along with a ${ }^{226} \mathrm{Ra}{ }^{238} \mathrm{U}$ age on shell of 78,000 years. Brigham-Grette and Hopkins (Brigham-Grette and Hopkins, 1995) compiled eleven ${ }^{14} \mathrm{C}$ dates on shell and wood from Pelukian deposits; nine of these ages were non-finite. Thermoluminescence dates on shells from Pelukian deposits on the Beaufort Sea coast obtained by Carter et al. (1986) ranged between 108 and 140 ka but were dismissed as inaccurate by Brigham-Grette and Hopkins (Brigham-Grette and Hopkins, 1995). While the amino acid racemization technique has proved useful in relative age dating and correlation of raised marine deposits located on widely separated Arctic coasts (Kaufman and Brigham-Grette, 1993b), it does not furnish estimates of absolute age (Miller and BrighamGrette, 1989; Mangerud and Svendsen, 1992). Furthermore, because of the slow rates of racemization in the Arctic, amino acid dating is unable to distinguish the substages of MIS 5 (Brigham-Grette and Hopkins, 1995). Because of these issues, the Pelukian has been broadly correlated with the eustatic sea level high-stand of MIS5e, which Brigham-Grette and Hopkins 
(Brigham-Grette and Hopkins, 1995) determine as 120-130 ka. Carter et al. ((Carter et al., 1986) obtained thermoluminescence (TL) ages on PT deposits near Teshekpuk Lake ranged between 108 and 140 ka, but Brigham-Grette and Hopkins (Brigham-Grette and Hopkins, 1995) dismissed these results as unreliable for methodological reasons and because the ages appeared to be too young to coincide with the MIS 5e highstand.

\subsection{Out-of-phase Arctic glaciations}

Out-of-phase glaciation during the Mid- to Late-Pleistocene has been observed repeatedly (see Hughes et al. 2013 and the references therein). Out-of-phase glaciation cases in point in North America include the Innuitian Ice Sheet that occupied the Canadian Arctic Archipelago (England et al., 2006), northernmost sectors of the Laurentide Ice Sheet (Dyke and Prest, 1987), the northwestern most portion of the Cordilleran Ice Sheet (Ward et al., 2007) and valley glaciers of the Brooks Range in northern Alaska (Kaufman et al., 2001). Other examples include portions of the Antarctic ice sheets (Hughes et al., 1977), the Arctic Ocean (Jakobsson et al., 2014), and NE Russia (Brigham-Grette et al., 2001; Barr and Clark, 2012). The timing of out-ofphase glaciations frequently includes Marine Isotope Stage 5 (de Vernal et al., 1991; BrighamGrette et al., 2001; Svendsen et al., 2004a; Barr and Clark, 2012; Miller et al., 1992) but has included MIS stages as far back as MIS 11(Pushkar et al., 1999). Although the timing of these earlier glaciations generally lack absolute ages.

Increased moisture availability and low summer insolation have been repeatedly cited as potential causes of out-of-phase glaciations at high-latitudes (Brigham-Grette, 2013a, 2001; Brigham-Grette et al., 2001; Pushkar et al., 1999; de Vernal et al., 1991; Miller and De Vernal, 1992; Spielhagen et al., 2004; Kaufman et al., 2001; Stauch and Gualtieri, 2008; Barr and Clark, 2012). During glacial periods, precipitation declines in the Arctic for three main reasons: 1) Cold air has less capacity to hold water vapor, 2) Massive ice sheets at mid-latitudes on the continents divert storm tracks away from the Arctic, and 3) Low stands in eustatic sea level and southward extension of sea ice increase the continentality of Arctic land masses and further isolate the Arctic basin from precipitation sources (Ewing and Donn, 1956; Mercer, 1970; Broecker, 1975; Dyke and Prest, 1987; de Vernal et al., 1991; Ward et al., 2007; Brigham-Grette, 2013b; 
Spielhagen et al., 2004; Brigham-Grette et al., 2001). These processes that starve the Arctic Basin of precipitation during full glacial times are reversed during interglacials when precipitation increases and - if summers are cool enough - ice sheets are able to develop.

The critical condition for the inception of ice sheets above $70^{\circ} \mathrm{N}$ may be a period when solar insolation is high in wintertime within the zone of the Westerlies $\left(30-60^{\circ} \mathrm{N}\right)$, but low in the Arctic during summer (Miller and De Vernal, 1992; Pushkar et al., 1999) (Fig. DR 2). This unique combination of winter warmth in the region where cyclonic storms form, and cold summers in the High Arctic that minimize melting of the previous winter's snowfall, may be required to kick-start ice sheet development in the Arctic Basin (Hughes et al., 2013; Svendsen et al., 2004; Hughes, and Gibbard, 2018; Spielhagen et al., 2004; Brigham-Grette et al., 2001; Miller et al., 1992). Interestingly, this particular insolation regime has occurred infrequently over the course of the Pleistocene, most recently at ca. 115 during MIS 5d (Fig. DR 2).

Could the insolation/moisture mechanism we suggest operated during MIS $5 \mathrm{~d}$ have also triggered earlier ice-sheet growth in the Arctic basin that was out of phase with mid-latitude ice sheets? A similar, large-magnitude period of warm mid-latitude winters and cold High Arctic summers occurred during the transition between MIS 7 (the interglacial before MIS 5) to MIS 6 (the penultimate glacial) (Fig DR 2) at a time when global ice volume was low (Shakun et al., 2015). 


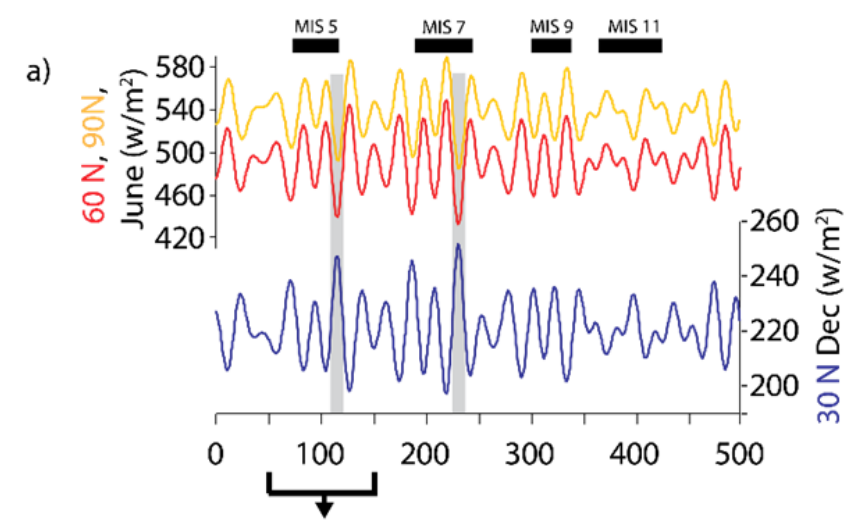

b)

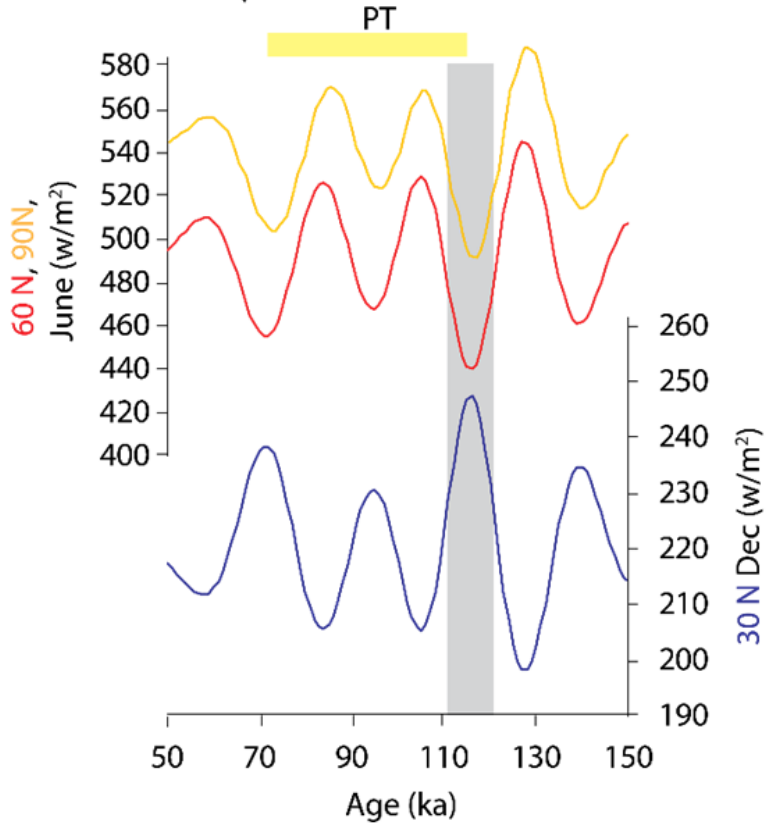

Figure DR 2: The high-latitude out-of-phase glaciation mechanism: a) Insolation curves for $60^{\circ}$ and $90^{\circ} \mathrm{N}$ in June (red and orange respectively) and for $30^{\circ} \mathrm{N}$ in December. Grey bars indicate times insolation patterns may have triggered glaciation due to a combination of deep troughs in summer insolation which limit ablation and peaks in mid-latitude winter insolation which promote moisture availability. b) Subset of the top plot illustrating how the timing of the PT corresponds to a dip in summer insolation at high latitudes and a peak in insolation at low latitudes between 50 and $150 \mathrm{ka}$.

3.3 Permafrost aggradation and associated frost heave as an influence over unit elevations

Permafrost aggradation and ice inflation has probably caused limited differential uplift of the PT deposits. Uplift from frost heave of the PT deposits would have been minimal due to their ice poor nature. Even for deposits containing $90 \%$ ice by volume (Kanevsky et al. 2012), the amount of uplift would amount to $<1 \mathrm{~m}$.

Data repository 


\subsection{Extralimital mollusk species}

Although the presence of extralimital mollusk species in PT deposits suggests the contemporary climate was warmer than today, an inference consistent with a MIS 5e age (Carter et al., 1986; McDougall, 1994; Brigham-Grette and Hopkins, 1995), none of the ca. 100 bivalve shells we found were in growth position, and most specimens were fragmented. Consequently, we infer these shells were reworked (Wehmiller et al., 1995) from older, MIS 5e deposits as sea level transgressed upslope. Because of the possibility of reworking (Wehmiller et al., 1995) and the large age-uncertainties inherent in amino-acid dating of these shells (Brigham-Grette and Hopkins, 1995), we do not consider the presence of extralimital mollusks to be a definitive criterion for assigning the PT to MIS 5e in age.

\subsection{Expanded caption for Figure 3}

Due to space limitations within the main text, further explanation of Figure 3 is provided here:

Figure 3. Alternate hypotheses to explain the mechanism and timing of the Pelukian transgression along the Beaufort Sea coast. In both panels, the red-dashed line is the altitude of the Pelukian barrier system; the grey-dashed line is relative sea level (RSL) today; the blue line depicts global, mean, eustatic sea level 0-160 ka (Shakun et al., 2015), and the grey shading indicates marine transgressions at our study site.

A: In the Double-Forebulge hypothesis, the study sites were uplifted above their contemporary RSL during MIS 6 by a glacial forebulge generated by the northwestern sector of the Laurentide Ice Sheet (LIS). As this forebulge collapsed during the later stages of MIS 5, RSL transgressed over the study sites and created the Pelukian barrier system. The Double-Forebulge hypothesis originates in the glacial and RSL history of the eastern seaboard of the United States (Scott et al., 2010; Dejong et al., 2015). This hypothesis is unlikely because the LGM's collapsing forebulge is currently located $1000 \mathrm{~km}$ to the east of the study area. 
B: In the preferred Grounded-Ice-Shelf hypothesis, an ice shelf fed by a terrestrial ice sheet developed over the Canadian Arctic Archipelago grounded along the continental shelf of the Beaufort Sea. The presence of glacial scouring at water depths of $1000 \mathrm{~m}$ on the Lomonosov Ridge in the central Arctic Ocean suggest this ice shelf projected some $90 \mathrm{~m}$ above sea level and thus been capable of causing roughly $30 \mathrm{~m}$ of isostatic depression where it was grounded along the Alaskan coast. This isostatic depression caused the Pelukian transgression. Fluctuations in ice-shelf extent and thickness may have caused multiple transgressions. As the ice sheet over the Canadian Arctic retreated and its associated ice shelf disappeared, the study region rebounded causing emergence above sea level before 57+/-10ka after which terrestrial loess deposition began. 


\section{Results}

\subsection{PT section descriptions}

\section{Walrus bluff}

The Walrus section (originally called NTB) begins at lake level, which lies approximately $1 \mathrm{~m}$ above present sea level (asl) (Fig DR3, DR4).

Unit 1: $100-175 \mathrm{~cm}$ (all elevations are given in centimeters above sea level): back-barrier lagoon. The lowest unit (Unit 1) consists of salty, anoxic, massive, dark-grey clayey silt containing occasional dolomite drop stones up to $10 \mathrm{~cm}$ in diameter (Fig DR5). We suggest that these drop stones are of the same genesis as the Flaxman boulders (Dinter 1985) which are thought to originate in the Amundsen Gulf (Rodeick, 1979). At the top of this unit, we found a metatarsal of a ringed seal (Pusa hispida) (Fig. DR6), and a humerus fragment from either a ribbon or spotted seal (Phoco largha or Histriophoca fasciata). Conifer driftwood up to a 1 meter in length is also present and one piece of this driftwood yielded a ${ }^{14} \mathrm{C}$ age of $>47.2 \mathrm{ka} \mathrm{BP} \mathrm{Fig.}$ DR6). We interpreted this unit to have formed within a low energy, anoxic environment, probably a lagoon. The upper boundary transitions gradually over approximately $30 \mathrm{~cm}$ as flaser beds become more frequent. We found no shells within this section (Fig. DR3).

Unit 2: back barrier tidal flats, $175-300 \mathrm{~cm}$ This unit consists of $125 \mathrm{~cm}$ of medium sand containing cosets of flaser beds composed of sandy clay with abundant gastropod shell fragments, none of which were in growth position. Wood fragments were commonly observed in association with the flaser beds. The upper boundary of Unit 2 transitions comformably into Unit 3. Two OSL samples from the base and top of Unit 2 date to $113 \pm 15 \mathrm{ka}$ (USU-1708) and $94 \pm$ 11 ka (USU-1709), respectively (Fig. DR3, Table DR4). We interpret this unit to be a tidally influenced environment, possibly a back-barrier area of tidal flats where overwash events carry in detrital wood, shell, and bone material. No drop stones were observed in this unit.

Unit 3: barrier beach, $300-600 \mathrm{~cm}$ Unit 3 consists of planar cross-beds of well-sorted medium sand containing abundant bivalve and mollusk shells, and thin beds of coarse sand and gravel. Bivalve and gastropod shells found include the extra-limital species Neptunea ventricosa and 
Boreoscala greenlandica but were not in growth position. Today the northern range limit of these two species is the north Pacific, so their presence requires sea surface temperatures warmer than today. The unit coarsens upwards into a massive bed of sandy gravel, lacking shells but containing a single walrus (Odobenus rosmarus) tooth (Fig. DR5). A small sand wedge penetrates through this layer, and is filled with well-sorted medium sand. The upper boundary of Unit 3 is an abrupt erosional unconformity. An OSL sample from the upper meter of Unit 3 yields and age of $94.8 \pm 12 \mathrm{ka}$ (USU-1710, Fig. DR3, Table DR4). We interpret this unit to be a barrier beach.

Unit 4: loess-like yedoma, $600-800 \mathrm{~cm}$ Unit 4 consists of massive, ice-rich, grey, sandy silt. An OSL age from $700 \mathrm{~cm}$ yielded an age of $58 \pm 8$ (Fig. DR3, Table DR3). A highly cryoturbated, peaty paleosol, $70 \mathrm{~cm}$ thick, is located at the base of the unit and a $3 \mathrm{~cm}$ thick ice vein runs through it horizontally but does not appear to penetrate the underlying unit. Herbaceous fragments from the paleosol yielded a non-finite ${ }^{14} \mathrm{C}$ age $(>47.1 \mathrm{ka} \mathrm{BP})$.

\section{Drip Bluff}

Drip Bluff section is located 500m east of Walrus (Fig. 1) and begins $\sim 700 \mathrm{~cm}$ above sea level (Fig DR.3). Unit 1 of Drip Bluff may be contemporaneous with Walrus's Unit 3, barrier beach deposits.

Unit1: gravelly beach, $700-780 \mathrm{~cm}$ The lower $80 \mathrm{~cm}$ of Drip Bluff is composed of planer beds of moderately sorted gravel and coarse sand (mean grain size for the unit is $700 \mu \mathrm{m}$ ) and has an abrupt upper boundary which lies in contact with Unit 2. An OSL sample from $30 \mathrm{~cm}$ below the upper boundary of this unit yielded and age of 78 +/- $11 \mathrm{ka}$ (USU-2101, Fig. DR3, Table DR4).

Unit 2: ice-rich silty sand sheet, $780-850 \mathrm{~cm}$ Unit 2 is composed of $70 \mathrm{~cm}$ of poorly sorted silty sandy organic- and ice-rich goo with rootlets, black organic inclusions and occasional pebbles. Mean grain size is $57 \mu \mathrm{m}$, very fine sand. The unit is capped by $30 \mathrm{~cm}$ of multiple moss-peat bands interbedded with root rich pebbly silt, capped by a distinct $2 \mathrm{~cm}$ band of coarse sand. We suggest that Unit 2 within Drip Bluff, may be the same as Unit 4 at Walrus Bluff.

Data repository 
Unit 3: sand sheet, $850-1030 \mathrm{~cm}$ Unit 3 is composed of $180 \mathrm{~cm}$ of sand sheet deposits composed of silty fine sand containing abundant fine rootlets. The upper $280 \mathrm{~cm}$ to the bluff top and modern day surface was not studied in detail but is composed of highly distorted organic and ice-rich loess deposits containing syngenetic ice wedges. No grain size analysis was conducted on this unit.

We interpret Drip Bluff to show gravelly beach deposits from MIS 3 which are overlain unconformably by Unit 2, an ice rich ice-rich silty sand sheet containing multiple paleosols.

\section{Black Lagoon Bluff}

Black Lagoon Bluff (Fig. DR3) section is located ca. $6 \mathrm{~km}$ east of Walrus and begins $3.5 \mathrm{~m}$ above sea-level and stretches approximately 10 meters along the shore.

Unit 1: anoxic lagoon, $350-530 \mathrm{~cm}$ This unit consists of salty anoxic clayey silt and contains rare detrital shell fragments which were not in growth position. Alternating planar beds of organic rich clay sand silt occur throughout the unit. Grain size distribution is unimodal and the sediment is poorly sorted medium silt to very fine sand. The mean grain size ranges from 7.0 to $76 \mu \mathrm{m}(\mathrm{n}=3)$. The transition into Unit 2 occurs over a gradual comfortable boundary spanning 60 $\mathrm{cm}$ and is OSL dated to $83+/-10$ (USU-2093, Fig. DR3, Table DR4).

We interpret this unit to be a low energy anoxic environment, likely a lagoon. Poor sediment sorting may be due to ice rafted debris during breakup (Barnes, 1982), or barrier over-wash events during storms.

Unit 2: tidal flat, $530-590 \mathrm{~cm}$ This unit consists of multiple composite cosets of flaser crosslaminations in muddy sand, recording flow towards $180^{\circ}$. The upper $10 \mathrm{~cm}$ of this unit contains scattered Naticidae (Table DR3). Grain size distribution is unimodal, well sorted silty sand, and has a mean grain size of $76.6 \mathrm{um}$. The transition from Unit 2 to Unit 3 is a planar erosional unconformity. 
Unit 3: tidal flat, $590-670 \mathrm{~cm}$ The lower $15 \mathrm{~cm}$ consist of planar cross beds of medium sand, with flow towards $130^{\circ}$. Worm tubes of varying morphology are common, along with a scattering of bivalves possibly in growth position. Sediment compaction prevented us from sampling identifiable fragments of bivalve shells for analysis. The upper $60 \mathrm{~cm}$ of Unit 3 consist primarily of upward coarsening medium sand characterized by trough cross beds and oscillation ripples. Grain size distribution is unimodal and poorly sorted. Mean grain size is $72 \mu \mathrm{m}$, very fine sand. An OSL sample from this unit yielded and age of 87+/- 11 (USU-2094, Fig. DR3, Table DR4). The upper boundary of Unit 3 transitions comformably into Unit 4.

Unit 4: tidal flat, $670-745 \mathrm{~cm}$ Unit 4 is composed of gravelly fine sand and contains flaser and oscillation ripples. The upper surface is conformable with the overlaying mud, Unit 5. Two small channels $30 \mathrm{~cm}$ deep and $80 \mathrm{~cm}$ wide, oriented to $130^{\circ}$, have incised into the top of Unit 4 and are infilled with gravelly muddy sand. We interpret these channels to be part of a dendritic channel network associated with tidal flow. Within this unit, grain size is unimodal and the sediment moderately sorted. Mean grain size is $121 \mu \mathrm{m}$, fine sand. An OSL sample from the upper $20 \mathrm{~cm}$ of Unit 4 yielded and age of 96+/-22 (USU-2097, Fig. DR3, Table DR4).

Unit 5: anoxic lagoon or thaw pond close to shore, $745-785 \mathrm{~cm}$ Unit 5 is composed of dark grey anoxic sandy silt. The upper boundary of Unit 5 is an erosional unconformity. Grain size distribution is unimodal and the sediment very poorly sorted. Mean grain size is $43 \mu \mathrm{m}$. Unlike the lower clayey silt unit, we found no shell fragments and the sediment was not salty to taste. Wood fragments were frequently present. The sediment was crudely stratified and contained occasional pebbles and sand lenses. An OSL sample from this unit yielded and age of 68 +/-9 (USU-2096, Fig. DR3, Table DR4). The middle of the unit has formed into a large diapir extending upwards and intruding into Unit 6.

Unit 6: pebbly beach, $785-1085 \mathrm{~cm}$ The base of unit six is composed of well sorted medium sand with a mean grain size of $282 \mu \mathrm{m}$, which coarsens upward. Throughout the unit as planar beds of pebbly sand with large lenses of poorly sorted coarse sand, and fine to coarse gravel. The upper meter of this section is obscured by slumping. An OSL sample from the lower $20 \mathrm{~cm}$ of this unit yielded an age of $80+/-10$ years (USU-2097, Fig. DR3, Table DR4).

Data repository 


\section{Fox Cub Bluff}

Fox Cub Buff (Fig. DR3) is located approximately 330 m east of Black Lagoon Bluff. Grain size analysis was conducted at 10 points up through the section (Fig DR. 7), and reveals an upward coarsening sequence.

Unit 1: anoxic lagoon, 100-150 cm Unit 1 consists of $50 \mathrm{~cm}$ of solid grey, poorly sorted, slightly gravelly mud which transitions conformably into the overlying unit. Mean grain size ranges from $5.3-6.0 \mu \mathrm{m}(\mathrm{n}=3)$.

Unit 2: tidal flats, $150-250 \mathrm{~cm}$ Unit 2 consists of $100 \mathrm{~cm}$ of muddy sand characterized by lenticular and wavy bedding. Grain size distribution in the lower $50 \mathrm{~cm}$ of the unit is bimodal, and the upper $50 \mathrm{~cm}$ moderately to poorly sorted and unimodal. The section is composed of 50 $\mathrm{cm}$ of solid grey organic rich clay which transitions comfortably into $100 \mathrm{~cm}$ of sandy, muddy, lenticular and wavy bedding. We interpret this unit to represent a transition from anoxic lagoonal conditions into silty tidal flats.

We interpret Fox Bluff to show a shallow tidally influenced coastal area. Upwards coarsening suggest a transition from a deeper to shallower environment, perhaps due to the migration of a barrier island, tidal channel or tidal delta. The presence of gravel may be due to ice rafted debris. Each unit was analyzed for diatoms but none were found.

\section{Lost Log Section}

The Lost Log section (Fig. DR3) is located approximately $6 \mathrm{~km}$ east of Walrus, close to Black Lagoon Bluff (Fig. 1).

Unit 1: anoxic lagoon, 100-150 cm Unit 1 is composed of dark grey salty poorly sorted fine silt containing no shells. The erosional upper boundary shows signs that blocks of sediment have been eroded away (rip up clasts) possibly due to freezing and plucking. 
Unit 2: tidal flats, $150-175 \mathrm{~cm}$ Unit 2 is a $25 \mathrm{~cm}$ thick trash layer containing planar beds of medium sand and black silty clay, interspersed with abundant wood and shell fragments, not in growth position. The black silty clay appears to be the same as the clay present in Unit 1, below. Small inclusions of coarse sand and pebbles occur throughout the unit.

Unit 3: barrier beach, $175-220 \mathrm{~cm}$ Unit 3 is composed of $45 \mathrm{~cm}$ of pebbly granules in a medium to coarse sand matrix with abundant shell fragments. This unit dips towards $170^{\circ}$ and contains rip up clasts, probably from lowest section.

Unit 4: barrier beach, $220-290 \mathrm{~cm}$ Unit 4 is composed of $70 \mathrm{~cm}$ of medium fine sand, in co-sets of fluvial planar cross beds. A band of rip up clasts and clay approximately $4 \mathrm{~cm}$ thick, runs through the center of the unit. Above this band is $30 \mathrm{~cm}$ of planar cross beds composed of shellfragment rich medium to fine sand. Beds within this unit dip towards $180^{\circ}$.

Unit 5: aeolian dune, $290-340 \mathrm{~cm}$ Unit 5 is composed of $50 \mathrm{~cm}$ of well sorted fine sand co-sets with tangential lower contacts. This unit is in the lea of the upper sandy berm feature (Unit 4). Beds within this unit generally dip towards $180^{\circ}$.

Unit 6: foreshore, $340-435 \mathrm{~cm}$ Unit 6 consists of $95 \mathrm{~cm}$ of planar beds and cross beds of granules, pebbles and coarse sand dipping toward $160^{\circ}$. The upper $50 \mathrm{~cm}$ of this unit includes occasional peaty rip up clasts.

\section{Admiralty Bay}

The Admiralty Bay section is located $70 \mathrm{~km}$ to the northwest of Teshekpuk Lake. The eastern shore of the Admiralty Bay intersects the PT beach ridge.

Unit 1: anoxic lagoon, $0-40 \mathrm{~cm}$ This unit consists of $40 \mathrm{~cm}$ of black anoxic sandy clay with distorted sub horizontal bedding. The upper boundary is abrupt although maybe not erosional.

Unit 2: tidal flats, $40-160 \mathrm{~cm}$ Unit 2 consists of medium sand, sub horizontal to massive in structure, which contains occasional wood and shell fragments. An OSL sample from the base of 
this unit dates to $81+/-10$ years (USU-2098, Figure DR3, Table DR4). The upper boundary transitions into Unit 3 and is an erosional unconformity.

Unit 3: pebbly beach, $160-220 \mathrm{~cm}$ Unit 3 consists of co-sets of cross bedded coarse sand with granules and pebbles dipping towards 250 degrees. Rare shell, coal and wood fragments were present.

Unit 4: sandy beach, $220-250 \mathrm{~cm}$ Unit 4 consists of undulating medium sand containing abundant shell fragments. An OSL sample from the middle of this unit dates $81+/-11$ years (USU-2099, Fig. DR3, Table DR3).

Unit 5: pond, possible of thermokarst origin, $250-270 \mathrm{~cm}$ Unit 5 is composed of massive grey sandy silt which undulates across the section. Occasional sub horizontal layers are present and the unit contains to shell and detrital wood fragments.

Unit 6: sand sheet, $270-470 \mathrm{~cm}$ Unit 6 is quite distorted with cryoturbated sand sheet and loess bands which appear to have been deposited subaerially. The top of this unit is obscured by slumping from the bluff top. 


\subsection{Flaxman boulders}

Occasional boulders of red and gray igneous rocks up to $30 \mathrm{~cm}$ in diameter occur in the lowest meter of the Walrus and Black Lagoon sections and are scattered along the northern shore of Teshekpuk Lake (Fig. DR5c). The lithologies of these erratic boulders match those in the stratigraphically separate and younger Flaxman member of the Gubik formation, which are known to be derived from the Canadian Arctic Archipelago (Fig. DR1) (MacCarthy, 1958; Rodeick, 1979). The presence of these Canadian Shield erratics suggests the mechanism responsible for their delivery occurred repeatedly during the Late Pleistocene. 


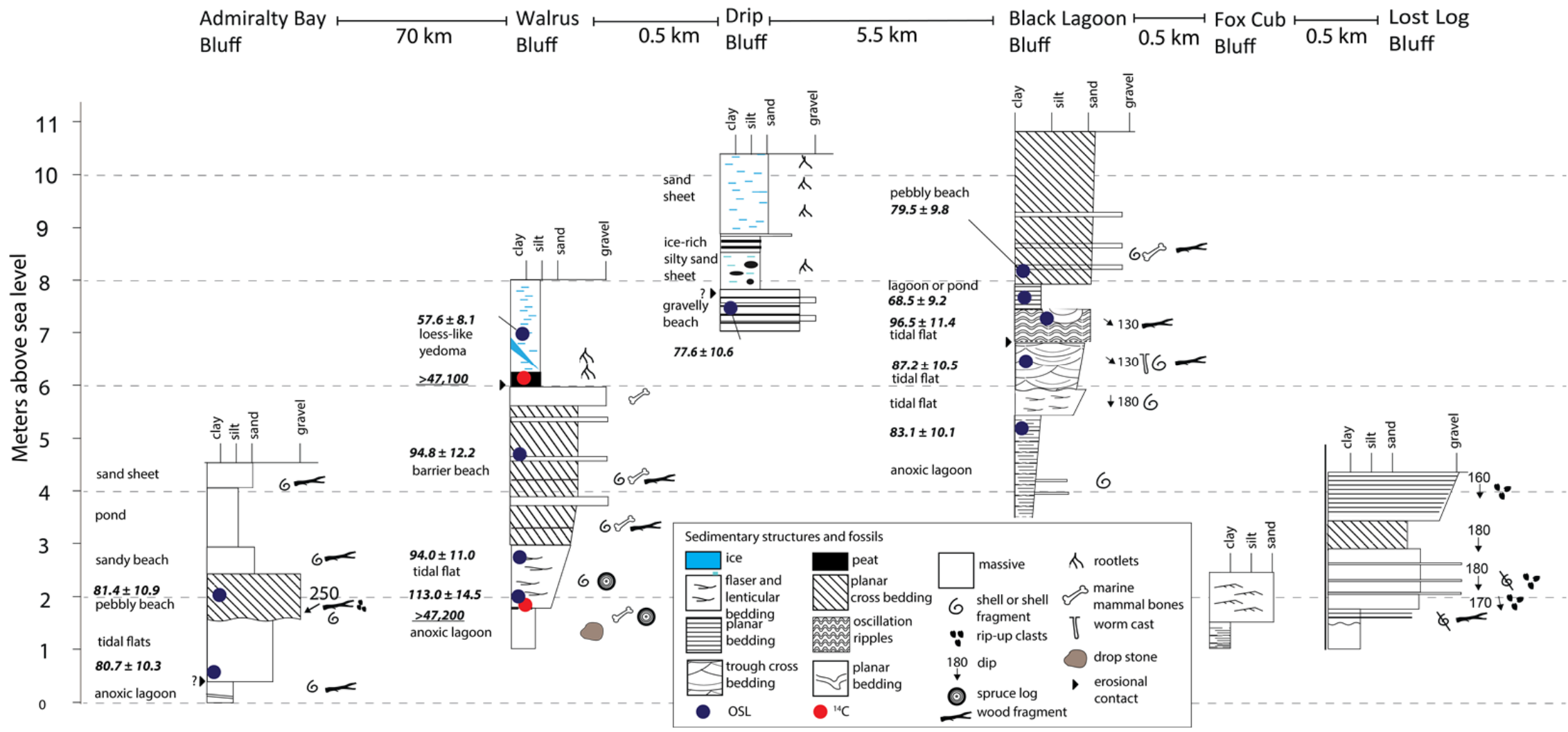

Figure DR3: Stratigraphy of the sections studied. 


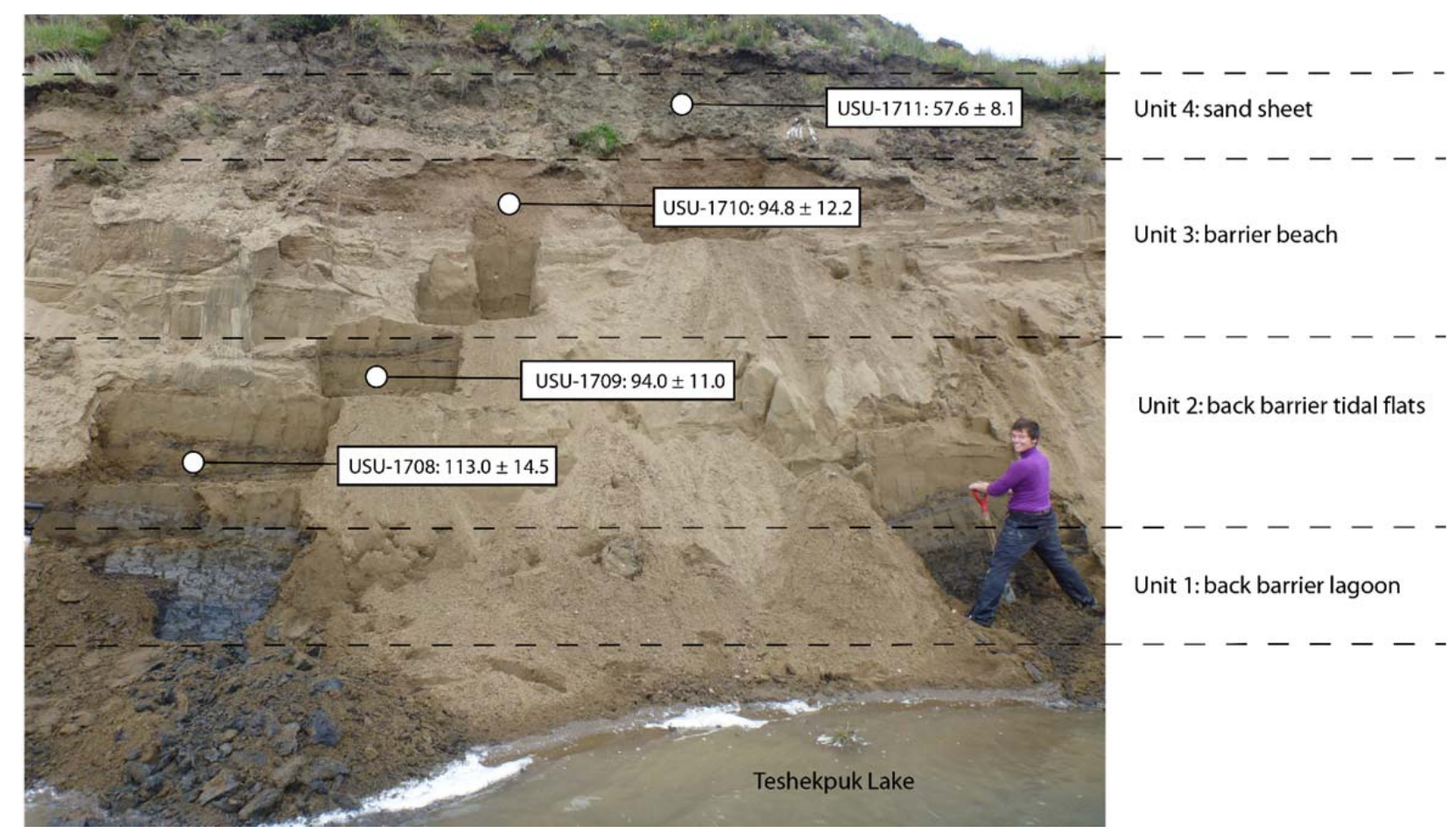

Figure DR4: Walrus Bluff with designated units and OSL ages. Note that photo was taken before the section covering OSL sample from Unit 4 was excavated and cleaned. 

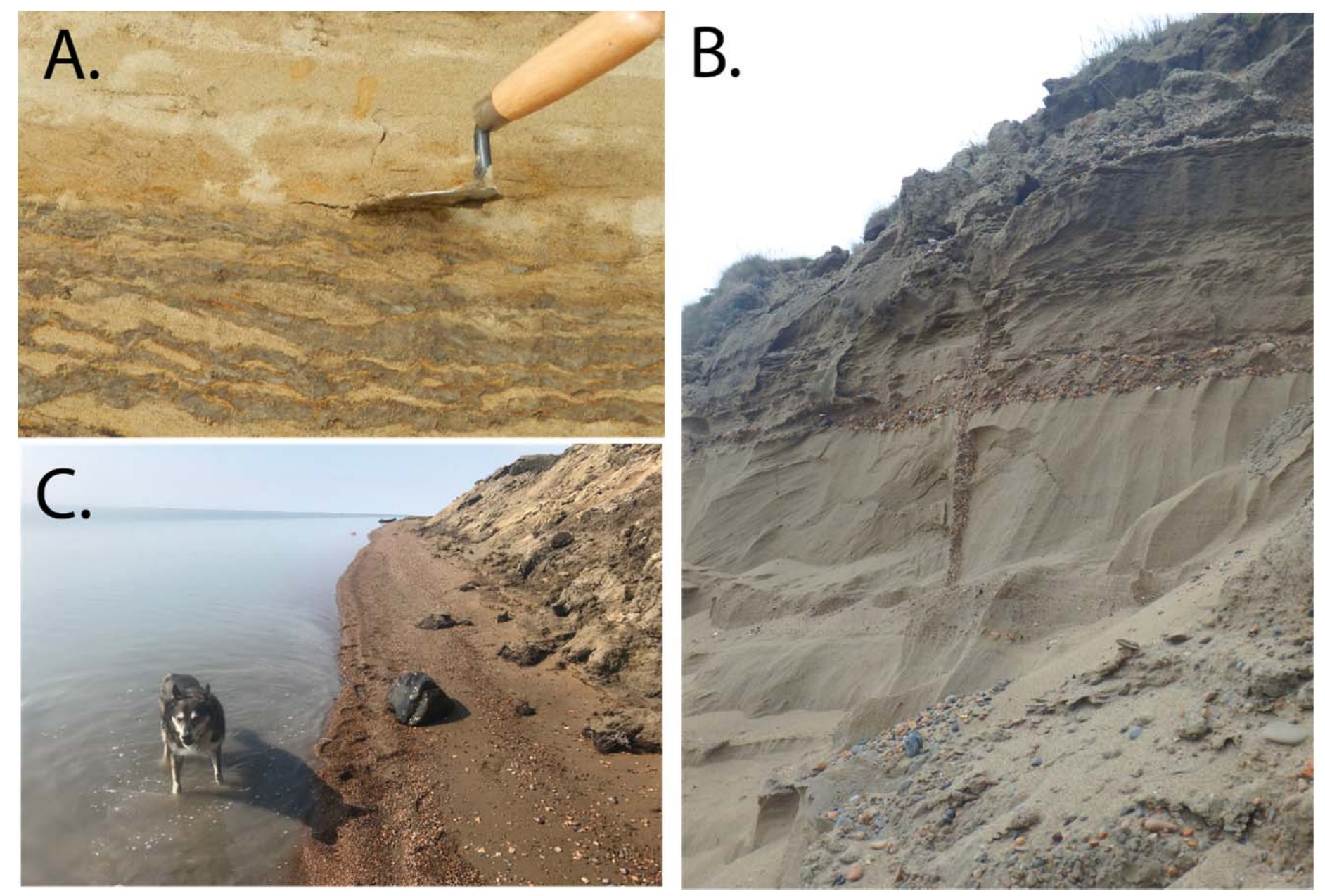

Figure DR5: Sedimentary features identified within the sections studied: A) lenticular bedding composed of sand lenses with silt drapes at Black Lagoon Bluff, trowel for scale; B) planar and planar cross bedding in beach unit near Walrus Bluff, sand wedge penetrating through gravel deposits; C) cobbles found at the base of Walrus bluff. 

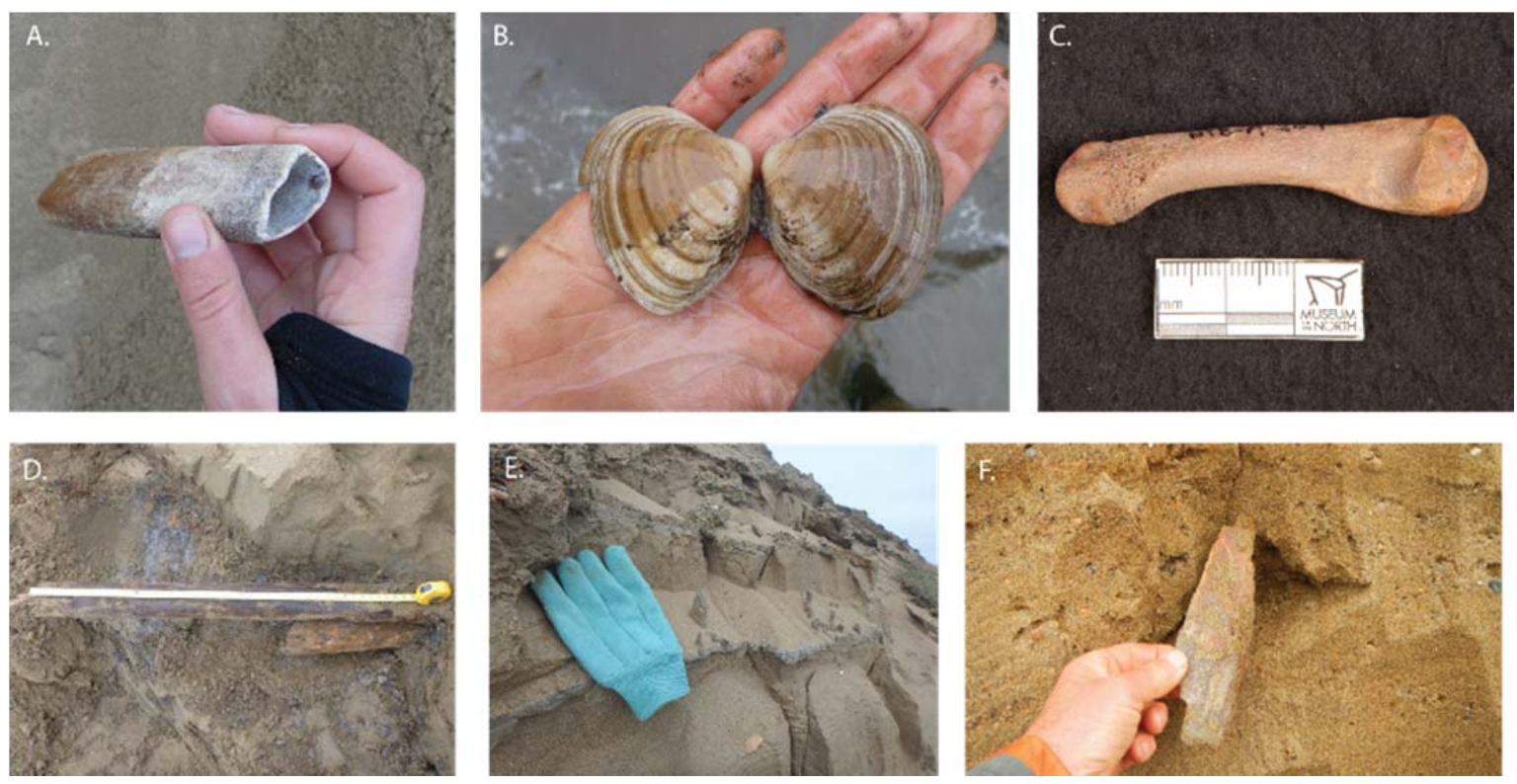

Figure DR6: A sub-sample of fossils found in-situ: A) Odobenus rosmarus (walrus) tooth from Walrus Bluff Unit 3; B) bivalve Macoma calcarean from Walrus Bluff, Unit 3; C) Pusa hispida (ringed seal) metatarsal, Walrus Bluff, Unit 1; D) coniferous driftwood with a diameter of $10 \mathrm{~cm}$, Walrus Bluff, Unit 1; E) worm hole casts, adjacent to Black Lagoon Bluff, Unit 6; F) Mammuthus primigenius (woolly mammoth) tusk fragment adjacent to Black Lagoon Bluff, Unit 6. 


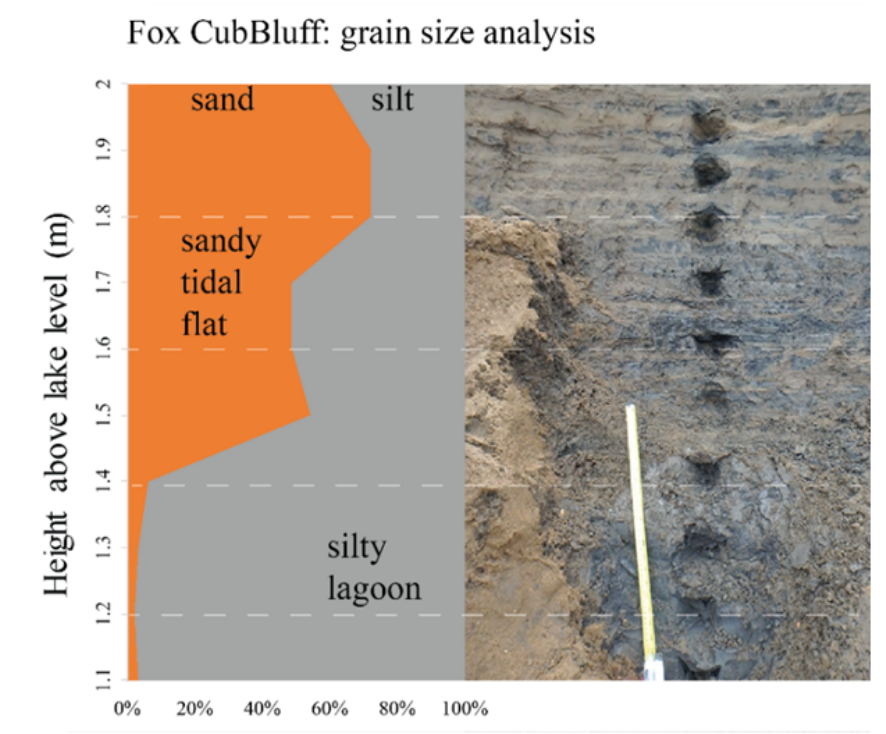

Figure DR7: Grain size composition for Fox Cub Bluff illustrating upwards coarsening probably as sea level transgressed. 
Table DR3: Shells found at study sites that were selected for identification

\begin{tabular}{|c|c|c|}
\hline & Species & Count \\
\hline \multicolumn{3}{|l|}{ Currently found in western Beaufort Sea } \\
\hline & Astarte borealis & 2 \\
\hline & Aulocofusus brevicauda? & 1 \\
\hline & Buccinum polare & 1 \\
\hline & Clinocardium ciliatum & 2 \\
\hline & Hiatella arctica & 5 \\
\hline & Macoma balthica & 1 \\
\hline & Macoma calcarea & 2 \\
\hline & Macoma moesta & 1 \\
\hline & Margarites costalis & 1 \\
\hline & Musculus niger & 1 \\
\hline & Mya truncata & 1 \\
\hline & Neptunea heros & 7 \\
\hline & Serripes groenlandicus & 5 \\
\hline & Beringius beringi & 2 \\
\hline & Total & 30 \\
\hline \multicolumn{3}{|l|}{ Extra-limital to the western Beaufort Sea } \\
\hline & Astarte elliptica & 3 \\
\hline & Serripes laperousii & 6 \\
\hline & Macoma cf. M. expansa & 1 \\
\hline & Mactromeris polynyma & 1 \\
\hline & Mya pseudoarenaria & 7 \\
\hline & Neptunea communis & 1 \\
\hline & Trichotropis bicarinata & 1 \\
\hline & Neptunea ventricosa? & 2 \\
\hline & Total & 22 \\
\hline
\end{tabular}


Table DR3 cont.: Shells found at study sites that were selected for identification

\begin{tabular}{lll}
\hline \hline & Species & Count \\
\hline Unknown distribution & Astarte sp. & 2 \\
& Boreoscala greenlandica & 2 \\
& Buccinidae & 1 \\
& Buccinum ciliatum & 1 \\
& Buccinum sp. & 5 \\
Cryptonatica sp. & 4 \\
fragments not identified & 3 \\
& Macoma sp. & 2 \\
& Naticidae & 4 \\
& Oenopota sp. & 1 \\
Polinices? sp. & 1 \\
Iphinopsis sp ? & 1 \\
Total & $\mathbf{2 6}$ \\
\hline
\end{tabular}




\subsection{OSL Chronology}

When all sections are considered together, OSL ages for coastal deposits range from $113.0 \pm 14.5$ to $68.5 \pm 9.2 \mathrm{ka}$. The lagoonal mud to sandy tidal flat unit transition at the base of Walrus Bluff exhibits the oldest coastal deposits age of $113.0+/-14.5 \mathrm{ka}$, possibly placing the beginning of the Pelukian transgression during MIS5e. The latest transition from lagoonal mud to sandy tidal flat deposits occurred at Black Lagoon 91.44 \pm 16 ka (Fig. DR2). The upper most coastal unit, a barrier beach, dates to $94.98 \pm 12.2$ at Walrus, $79.50 \pm 9.75$ at Black Lagoon, and $77.63 \pm 10.56$ at Drip Bluff (Fig. DR2). 
Table DR4: Optically stimulated luminescence ages. Walrus Bluff named NTB and Admiralty Bay Bluff named Ocean bluff here.

\begin{tabular}{|c|c|c|c|c|c|c|c|}
\hline $\begin{array}{l}\text { Sample } \\
\text { num. }\end{array}$ & USU num. & $\begin{array}{l}\text { Num. of } \\
\text { aliquots }^{1}\end{array}$ & $\begin{array}{l}\text { Dose rate } \\
(\mathrm{Gy} / \mathrm{ka})\end{array}$ & $\begin{array}{c}\mathrm{D}_{\mathrm{E}}^{2} \pm 1 \sigma \\
(\mathrm{Gy})\end{array}$ & $\mathrm{OD}^{3}(\%)$ & $\begin{array}{c}\text { Age } \pm 1 \sigma \\
(\mathrm{ka})\end{array}$ & OSL \\
\hline NTB-A-5 & USU-1708 & $18(27)$ & $0.87 \pm 0.07$ & $98.4 \pm 5.4$ & $18.6 \pm 4.8$ & $113.0 \pm 14.5$ & OSL \\
\hline $\begin{array}{c}\text { NTB-A- } \\
11\end{array}$ & USU-1709 & $21(31)$ & $0.75 \pm 0.04$ & $70.6 \pm 4.2$ & $22.5 \pm 5.0$ & $94.0 \pm 11.0$ & OSL \\
\hline $\begin{array}{c}\text { NTB-A- } \\
17\end{array}$ & USU-1710 & $23(42)$ & $0.70 \pm 0.05$ & $66.5 \pm 6.7$ & $44.4 \pm 7.7$ & $94.8 \pm 12.2$ & OSL \\
\hline NTB-C-6 & USU-1711 & 19 (39) & $1.39 \pm 0.12$ & $80.1 \pm 5.6$ & $25.3 \pm 6.2$ & $57.6 \pm 8.1$ & OSL \\
\hline $\begin{array}{c}\text { Black } \\
\text { Lagoon } 1\end{array}$ & USU-2093 & $19(28)$ & $1.55 \pm 0.10$ & $128.4 \pm 7.1$ & $18.0 \pm 4.9$ & $83.1 \pm 10.1$ & OSL \\
\hline $\begin{array}{c}\text { Black } \\
\text { Lagoon } 2\end{array}$ & USU-2094 & $25(58)$ & $1.19 \pm 0.07$ & $104.1 \pm 6.5$ & $21.5 \pm 5.8$ & $87.2 \pm 10.5$ & OSL \\
\hline $\begin{array}{c}\text { Black } \\
\text { Lagoon } 3\end{array}$ & USU-2095 & $24(43)$ & $1.08 \pm 0.06$ & $104.6 \pm 6.3$ & $20.4 \pm 5.6$ & $96.5 \pm 11.4$ & OSL \\
\hline $\begin{array}{c}\text { Black } \\
\text { Lagoon } 4\end{array}$ & USU-2096 & $17(28)$ & $1.99 \pm 0.18$ & $136.5 \pm 6.5$ & $9.5 \pm 5.7$ & $68.5 \pm 9.2$ & OSL \\
\hline $\begin{array}{c}\text { Black } \\
\text { Lagoon } 5\end{array}$ & USU-2097 & $16(40)$ & $0.82 \pm 0.05$ & $65.5 \pm 4.5$ & $19.3 \pm 6.4$ & $79.5 \pm 9.8$ & OSL \\
\hline $\begin{array}{l}\text { Ocean } \\
\text { Bluff } 1\end{array}$ & USU-2098 & $24(55)$ & $0.86 \pm 0.05$ & $69.8 \pm 5.2$ & $29.2 \pm 6.2$ & $80.7 \pm 10.3$ & OSL \\
\hline $\begin{array}{l}\text { Ocean } \\
\text { Bluff } 2\end{array}$ & USU-2099 & 21 (39) & $0.90 \pm 0.05$ & $73.0 \pm 6.4$ & $34.6 \pm 7.1$ & $81.4 \pm 10.9$ & OSL \\
\hline Drip-1 & USU-2101 & $25(50)$ & $1.07 \pm 0.06$ & $83.0 \pm 7.6$ & $41.7 \pm 7.0$ & $77.6 \pm 10.6$ & OSL \\
\hline \multicolumn{8}{|c|}{$\begin{array}{l}{ }^{1} \text { OSL age analysis using the single-aliquot regenerative-dose procedure of Murray and Wintle(Murray and Wintle, 2000a) on } 2 \mathrm{~mm} \text { small- } \\
\text { aliquots of quartz sand. Number of aliquots used in age calculation and number of aliquots analyzed in parentheses. }\end{array}$} \\
\hline
\end{tabular}

Data repository 
Figure DR8: Quartz OSL Equivalent dose (DE) Radial Plots

USU-1708, NTB-A-5

CAM DE $=98.4 \pm 5.4 \mathrm{~Gy}$

$\mathrm{n}=18(27)$
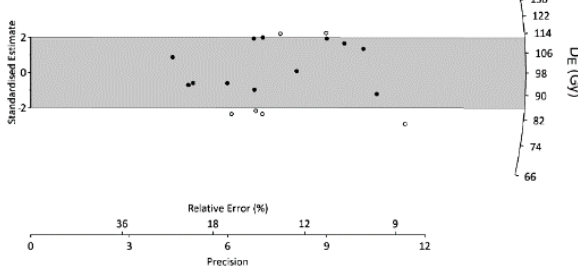

USU-1709, NTB-A-11

CAM $D_{E}=70.6 \pm 4.2 \mathrm{~Gy}$

$\mathrm{n}=21$ (31)
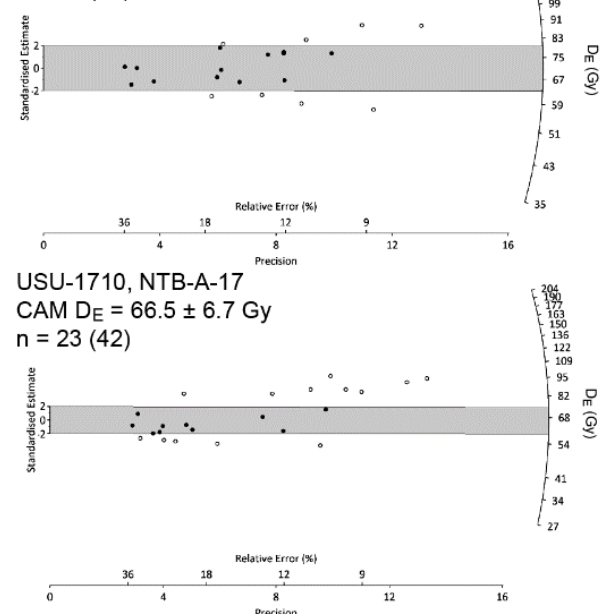

USU-1711, NTB-C-6

CAM $D_{E}=80.1 \pm 5.6 \mathrm{~Gy}$

$\mathrm{n}=19$ (39)
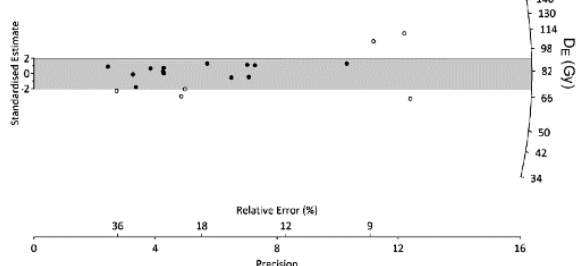

USU-2093, Black Lagoon 1

CAM $D_{E}=128.4 \pm 7.1$ Gy

$\mathrm{n}=19(28)$

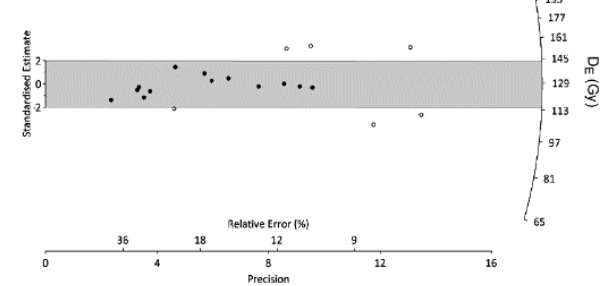

USU-2094, Black Lagoon 2

CAM $D_{E}=104.1 \pm 6.5 \mathrm{~Gy}$

$\mathrm{n}=25$ (58)

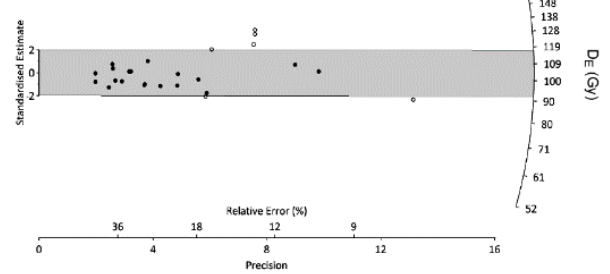

USU-2095, Black Lagoon 3

CAM $D_{E}=104.6 \pm 6.3 \mathrm{~Gy}$

$n=24$ (43)
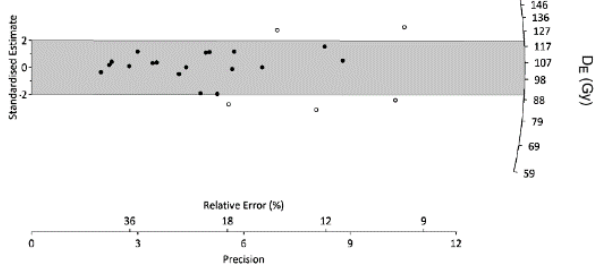

USU-2096, Black Lagoon 4 CAM $D_{E}=136.5 \pm 6.5 \mathrm{~Gy}$

$\mathrm{n}=17(28)$
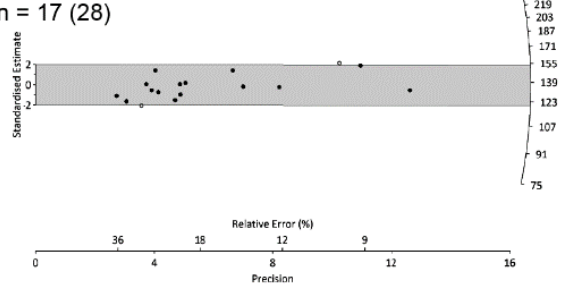

USU-2097, Black Lagoon 5 CAM $D_{E}=65.5 \pm 4.5 \mathrm{~Gy}$ $\mathrm{n}=16(40)$
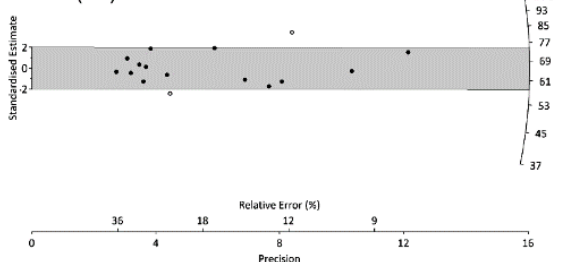

USU-2098, Ocean Bluff 1

CAM $D_{E}=69.8 \pm 5.2 \mathrm{~Gy}$

$\mathrm{n}=24$ (55)

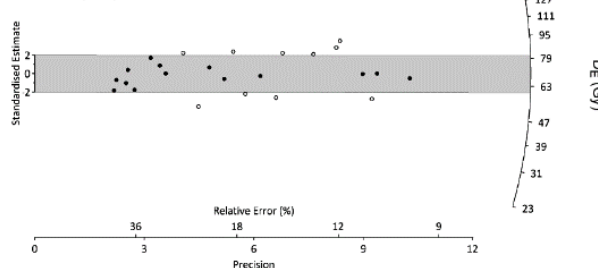

USU-2099, Ocean Bluff 2

CAM $D_{E}=73.0 \pm 6.4$ Gy

$\mathrm{n}=21(39)$
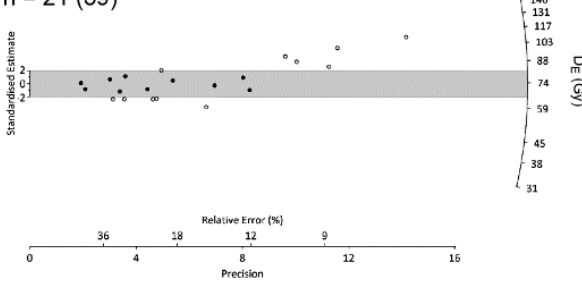

USU-2101, Drip-1

CAM $D_{E}=83.0 \pm 7.6 \mathrm{~Gy}$

$\mathrm{n}=25(50)$

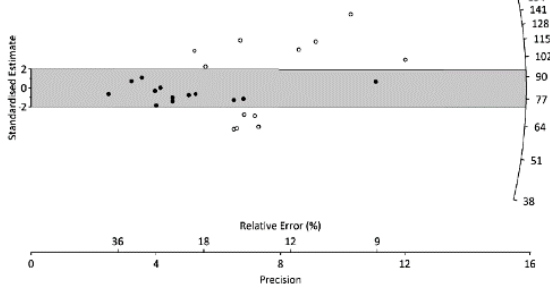

Data repository 


\section{REFERENCES}

Aitken, M.J., 1985, Thermoluminescence Dating: Florida, Academic Press.

Aitken, M.J., and Alldred, J.C., 1972, The assessment of error limits in thermoluminescent dating: Archaeometry, v. 14, p. 257-267, doi: 10.1111/j.1475-4754.1972.tb00068.x.

Aitken, M.J., and Xie, J., 1990, Moisture correction for annual gamma dose: Ancient TL, v. 8, p. 6-9.

Barnes, P.W., 1982, Marine ice-pushed boulder ridge, Beaufort Sea, Alaska: Arctic, v. 35, p. 312-316, doi: 10.14430/arctic2330.

Barr, I.D., and Clark, C.D., 2012, Late Quaternary glaciations in Far NE Russia; combining moraines, topography and chronology to assess regional and global glaciation synchrony: Quaternary Science Reviews, v. 53, p. 72-87, doi: 10.1016/j.quascirev.2012.08.004.

Bateman, M.D., 2008, Luminescence dating of periglacial sediments and structures: Boreas, v. 37, p. 574-588, doi: 10.1111/j.1502-3885.2008.00050.x.

Bateman, M.D., and Murton, J.B., 2006, The chronostratigraphy of Late Pleistocene glacial and periglacial aeolian activity in the Tuktoyaktuk Coastlands, NWT, Canada: Quaternary Science Reviews, v. 25, p. 2552-2568, doi: 10.1016/j.quascirev.2005.07.023.

Blott, S.J., and Pye, K., 2001, Gradistat: A grain size distribution and statistics package for the analysis of unconsolidated sediments: Earth Surface Processes and Landforms, v. 26, p. 1237-1248, doi: 10.1002/esp.261.

Bøtter-Jensen, L., Andersen, C.E., Duller, G.A.T., and Murray, A.S., 2003, Developments in radiation, stimulation and observation facilities in luminescence measurements, in Radiation Measurements, v. 37, p. 535-541, doi: 10.1016/S1350-4487(03)00020-9.

Brennan, B.J., 2003, Beta doses to spherical grains, in Radiation Measurements, v. 37, p. 299303, doi: 10.1016/S1350-4487(03)00011-8.

Brigham-Grette, J., 2013a, A fresh look at Arctic ice sheets: Nature Geoscience, v. 6, p. 807808, doi: 10.1038/ngeo1960.

Brigham-Grette, J., 2001, New perspectives on Beringian Quaternary paleogeography, stratigraphy, and glacial history: Quaternary Science Reviews, v. 20, p. 15-24, doi: 10.1016/S0277-3791(00)00134-7.

Brigham-Grette, J., 2013b, Palaeoclimate: A fresh look at Arctic ice sheets: Nature Geoscience, v. 6, p. 807-808, doi: 10.1038/ngeo1960.

Brigham-Grette, J., and Hopkins, D.M., 1995, Emergent marine record and paleoclimate of the last interglaciation along the northwest Alaskan coast: Quaternary Research, v. 43, p. 159173.

Brigham-Grette, J., Hopkins, D.M., Ivanov, V.F., Basilyan, A.E., Benson, S.L., Heiser, P.A., and Pushkar, V.S., 2001, Last interglacial (isotope stage 5) glacial and sea-level history of coastal Chukotka Peninsula and St. Lawrence Island, Western Beringia: Quaternary Science Reviews, v. 20, p. 419-436, doi: 10.1016/S0277-3791(00)00107-4.

Data repository 
Broecker, W.S., 1975, Climatic Change: Are We on the Brink of a Pronounced Global Warming? Science, v. 189, p. 460-463, doi: 10.1126/science.189.4201.460.

Carter, L.D., Brigham-Grette, J., and Hopkins, D.M., 1986, Late Cenozoic marine transgressions of the Alaskan Arctic coastal plain., in Correlation of Quaternary deposits and events around the margin of the Beaufort Sea, p. 21-26.

Dejong, B.D., Bierman, P.R., Newell, W.L., Rittenour, T.M., Mahan, S.A., Balco, G., and Rood, D.H., 2015, Pleistocene relative sea levels in the Chesapeake Bay region and their implications for the next century: GSA Today, v. 25, p. 4-10, doi: 10.1130/GSATG223A.1.4.

Dyke, A.S., and Prest, V.K., 1987, Late Wisconsinan and Holocene History of the Laurentide Ice Sheet: Géographie physique et Quaternaire, v. 41, p. 237, doi: 10.7202/032681ar.

England, J., Atkinson, N., Bednarski, J., Dyke, A.S., Hodgson, D.A., and Ó Cofaigh, C., 2006, The Innuitian Ice Sheet: configuration, dynamics and chronology: Quaternary Science Reviews, v. 25, p. 689-703, doi: 10.1016/j.quascirev.2005.08.007.

Ewing, M., and Donn, W.L., 1956, A theory of ice ages: Science, v. 123, p. 1061-1066.

Forman, S.L., Pierson, J., Gómez, J., Brigham-Grette, J., Nowaczyk, N.R., and Melles, M., 2007, Luminescence geochronology for sediments from Lake El'gygytgyn, northeast Siberia, Russia: Constraining the timing of paleoenvironmental events for the past $200 \mathrm{ka}$ : Journal of Paleolimnology, v. 37, p. 77-88, doi: 10.1007/s10933-006-9024-7.

Galbraith, R.F., and Roberts, R.G., 2012, Statistical aspects of equivalent dose and error calculation and display in OSL dating: An overview and some recommendations: Quaternary Geochronology, v. 11, p. 1-27, doi: 10.1016/j.quageo.2012.04.020.

Guérin, G., Mercier, N., and Adamiec, G., 2011, Dose-rate conversion factors: update: Ancient TL, v. 29, p. 5-8, http://www.aber.ac.uk/temp-ancient-tl/issue16_2/adamiec_atl_16(2)_3750.pdf.

Hopkins, D.M., 1967, Quaternary Marine Transgressions in Alaska, in Hopkins, D.M. ed., The Bering land bridge, Stanford, CA, Stanford University Press.

Hughes, P. D., and Gibbard, P.L., 2018, Global glacier dynamics during 100 ka Pleistocene glacial cycles: Quaternary Research,.

Hughes, T., Denton, G.H., and Grosswald, M.G., 1977, Was there a late-Würm Arctic ice sheet? Nature, v. 266, p. 596-602, doi: 10.1038/266596a0.

Hughes, P.D., Gibbard, P.L., and Ehlers, J., 2013, Timing of glaciation during the last glacial cycle: Evaluating the concept of a global "Last Glacial Maximum" (LGM): Earth-Science Reviews, v. 125, p. 171-198, doi: 10.1016/j.earscirev.2013.07.003.

Jakobsson, M., Andreassen, K., Bjarnadóttir, L.R., Dove, D., Dowdeswell, J.A., England, J.H., Funder, S., Hogan, K., Ingólfsson, Ó., Jennings, A., Krog Larsen, N., Kirchner, N., Landvik, J.Y., Mayer, L., et al., 2014, Arctic Ocean glacial history: Quaternary Science Reviews, v. 92, p. 40-67, doi: 10.1016/j.quascirev.2013.07.033. 
Jakobsson, M., Nilsson, J., Anderson, L., Backman, J., Björk, G., Cronin, T.M., Kirchner, N., Koshurnikov, A., Mayer, L., Noormets, R., O’Regan, M., Stranne, C., Ananiev, R., Barrientos Macho, N., et al., 2016, Evidence for an ice shelf covering the central Arctic Ocean during the penultimate glaciation: Nature Communications, v. 7, doi: 10.1038/ncomms10365.

Kaufman, D.S., and Brigham-Grette, J., 1993a, Aminostratigraphic correlations and paleotemperature implications, Pliocene-Pleistocene high-sea-level deposits, northwestern Alaska: Quaternary Science Reviews, v. 12, p. 21-33.

Kaufman, D.S., and Brigham-Grette, J., 1993b, Aminostratigraphic correlations and paleotemperature implications, Pliocene-Pleistocene high-sea-level deposits, northwestern Alaska: Quaternary Science Reviews, v. 12, p. 21-33, doi: 10.1016/0277-3791(93)90046-O.

Kaufman, D.S., Manley, W.F., Forman, S.L., and Layer, P.W., 2001, Pre-late-Wisconsin glacial history, coastal Ahklun Mountains, southwestern Alaska - New amino acid, thermoluminescence, and 40 Ar/39 Ar results: Quaternary Science Reviews, v. 20, p. $337-$ 352, doi: 10.1016/S0277-3791(00)00112-8.

MacCarthy, G.R., 1958, Glacial boulders on the arctic coast of Alaska: Arctic, v. 11, p. 71-86.

Mangerud, J., and Svendsen, J.I., 1992, The last interglacial-glacial period on spitsbergen, Svalbard: Quaternary Science Reviews, v. 11, p. 633-664, doi: 10.1016/02773791(92)90075-J.

McDougall, K.A., 1994, Late Cenozoic benthic foraminifers of the HLA borehole series, Beaufort Sea shelf, Alaska:, http://pubs.er.usgs.gov/publication/b2055.

Mercer, J.H., 1970, A former ice sheet in the Arctic Ocean? Palaeogeography, Palaeoclimatology, Palaeoecology, v. 8, p. 19-27, doi: 10.1016/0031-0182(70)90076-3.

Miller, G.H., and Brigham-Grette, J., 1989, Amino acid geochronology: Resolution and precision in carbonate fossils: Quaternary International, v. 1, p. 111-128, doi: 10.1016/1040-6182(89)90011-6.

Miller, G.H., Funder, S., De Vernal, A., and Andrews, J.T., 1992, Timing and character of the last interglacial-glacial transition in the eastern Canadian Arctic and northwest Greenland: SPECIAL PAPERS-GEOLOGICAL SOCIETY OF AMERICA, p. 223.

Miller, G.H., and De Vernal, A., 1992, Will Greenhouse Warming Lead to Northern-Hemisphere Ice-Sheet Growth: Nature, v. 355, p. 244-246.

Murray, A.S., and Wintle, A.G., 2000a, Luminescence dating of quartz using an improved single-aliquot regenerative-dose protocol: Radiation Measurements, v. 32, p. 57-73, doi: 10.1016/S1350-4487(99)00253-X.

Murray, A.S., and Wintle, A.G., 2000b, Luminescence dating of quartz using an improved single-aliquot regenerative-dose protocol: Radiation Measurements, v. 32, p. 57-73, doi: 10.1016/S1350-4487(99)00253-X.

Murray, A.S., and Wintle, A.G., 2003, The single aliquot regenerative dose protocol: Potential for improvements in reliability, in Radiation Measurements, v. 37, p. 377-381, doi:

Data repository 


\subsection{6/S1350-4487(03)00053-2.}

Prescott, J.R., and Hutton, J.T., 1994, Cosmic ray contributions to dose rates for luminescence and ESR dating: Large depths and long-term time variations: Radiation Measurements, v. 23, p. 497-500, doi: 10.1016/1350-4487(94)90086-8.

Pushkar, V.S., Roof, S.R., Cherepanova, M. V., Hopkins, D.M., and Brigham-Grette, J., 1999, Paleogeographic and paleoclimatic significance of diatoms from middle Pleistocene marine and glaciomarine deposits on Baldwin Peninsula, northwestern Alaska: Palaeogeography, Palaeoclimatology, Palaeoecology, v. 152, p. 67-85, doi: 10.1016/S0031-0182(99)00040-1.

Rodeick, C.A., 1979, The origin, distribution, and depositional history of gravel deposits on the Beaufort Sea Continental Shelf, Alaska:, http://pubs.er.usgs.gov/publication/ofr79234.

Scott, T.W., Swift, D.J.P., Whittecar, G.R., and Brook, G.A., 2010, Glacioisostatic influences on Virginia's late Pleistocene coastal plain deposits: Geomorphology, v. 116, p. 175-188, doi: 10.1016/j.geomorph.2009.10.017.

Shakun, J.D., Lea, D.W., Lisiecki, L.E., and Raymo, M.E., 2015, An 800-kyr record of global surface ocean $\delta^{18} \mathrm{O}$ and implications for ice volume-temperature coupling: Earth and Planetary Science Letters, v. 426, p. 58-68, doi: 10.1016/j.eps1.2015.05.042.

Spielhagen, R.F., Baumann, K.H., Erlenkeuser, H., Nowaczyk, N.R., Nørgaard-Pedersen, N., Vogt, C., and Weiel, D., 2004, Arctic Ocean deep-sea record of northern Eurasian ice sheet history, in Quaternary Science Reviews, v. 23, p. 1455-1483, doi: 10.1016/j.quascirev.2003.12.015.

Stauch, G., and Gualtieri, L., 2008, Late quaternary glaciations in northeastern Russia: Journal of Quaternary Science, v. 23, p. 545-558, doi: 10.1002/jqs.1211.

Svendsen, J.I., Alexanderson, H., Astakhov, V.I., Demidov, I., Dowdeswell, J.A., Funder, S., Gataullin, V., Henriksen, M., Hjort, C., Houmark-Nielsen, M., Hubberten, H.W., Ingólfsson, Ó., Jakobsson, M., Kjær, K.H., et al., 2004a, Late Quaternary ice sheet history of northern Eurasia, in Quaternary Science Reviews, v. 23, p. 1229-1271, doi: 10.1016/j.quascirev.2003.12.008.

Svendsen, J.I., Alexanderson, H., Astakhov, V.I., Demidov, I., Dowdeswell, J. a., Funder, S., Gataullin, V., Henriksen, M., Hjort, C., Houmark-Nielsen, M., Hubberten, H.W., Ingólfsson, Ó., Jakobsson, M., Kjær, K.H., et al., 2004b, Late Quaternary ice sheet history of northern Eurasia: Quaternary Science Reviews, v. 23, p. 1229-1271, doi: 10.1016/j.quascirev.2003.12.008.

de Vernal, A., Miller, G.H., and Hillaire-Marcel, C., 1991, Paleoenvironments of the last interglacial in northwest north atlantic region and adjacent mainland Canada: Quaternary International, v. 10-12, p. 95-106, doi: 10.1016/1040-6182(91)90043-N.

Ward, B.C., Bond, J.D., and Gosse, J.C., 2007, Evidence for a 55-50 ka (early Wisconsin) glaciation of the Cordilleran ice sheet, Yukon Territory, Canada: Quaternary Research, v. 68, p. 141-150, doi: 10.1016/j.yqres.2007.04.002.

Wehmiller, J.F., York, L.L., and Bart, M.L., 1995, Amino acid racemization geochronology of reworked Quaternary mollusks on U.S. Atlantic coast beaches: implications for

Data repository 
chronostratigraphy, taphonomy, and coastal sediment transport: Marine Geology, v. 124, p. 303-337, doi: 10.1016/0025-3227(95)00047-3.

Wintle, A.G., 1997, Luminescence dating: laboratory procedures and protocols: Radiation Measurements, v. 27, p. 769-817, doi: 10.1016/S1350-4487(97)00220-5. 